\title{
Does Teacher Education Program Affect on Development of Teacher Candidates' Bioethical Values, Scientific Literacy Levels and Empathy Skills?
}

\author{
Duygu Turgut ${ }^{1} \&$ Zeha Yakar ${ }^{1}$ \\ ${ }^{1}$ Science Education Department, Pamukkale University, Denizli, Turkey \\ Correspondence: Zeha Yakar, Science Education Department, Pamukkale University, Denizli, Turkey.
}

Received: November 25, 2019

Accepted: February 1, 2020

Online Published: April 18, 2020

doi:10.5539/ies.v13n5p80

URL: https://doi.org/10.5539/ies.v13n5p80

\begin{abstract}
The aim of this study is to evaluate science teacher candidates based on bioethical values, scientific literacy level and empathy skills and to determine their associations. Therefore, descriptive model was used for the study. The sample of the study consists total of 286 teacher candidates from first, second, third and fourth grade of Faculty of Education Science Teaching department. Results of the study revealed that bioethical values for "Benefits of Biotechnology Applications", "Science and Ethics", "Reproductive Technologies and Cloning", "Controlling the Genetic Interventions" subscales were increased with school year in science teacher candidates. In addition, science literacy of science teacher candidates for "Nature of Science" and "Science-Technology-Society Relation" subscales were also increased with school year. The study also found a positive relation between bioethical values for two subscales of bioethical values, "Benefits of Biotechnology Applications" and "Controlling the Genetic Interventions", and science literacy for "Nature of Science" subscales in science teacher candidates. Similarly, a positive relation was found between bioethical values for two subscales, "Benefits of Biotechnology Applications" and "Controlling the Genetic Interventions", and science literacy for "Science-Technology-Society Relation" subscale in science teacher candidates. Analysis results showed a positive relation between bioethical values and empathy skills of science teacher candidates. In other words, the higher the teacher's empathy skills, the higher their bioethical values.
\end{abstract}

Keywords: science education, bioethical value, scientific literacy, empathy

\section{Introduction}

We all are living in an exciting, rapidly changing, technology-dependent, and challenging world. Our world is changing so fast that it is impossible not to realize that what we have brought up today is only a few years ago in the imagination of people. Especially scientific and technological developments turn many dreams into reality. Last few centuries witnessed major advancements in science and technology. This increase in knowledge and the accompanying developments leaves all of us facing moral and ethical dilemmas. For example, when the "first draft" of human genome was published back in June 2000, stories reported this as a milestone in the history of mankind. And some scientists highlighted that this discovery could be vulnerable against misuse. New technologies reminding science fiction like manipulations to human genetics, applications such as psychotherapy techniques, behavioral control mechanisms, use of life support units in comatose patients cause awareness and concern in the society and will continue to do so (Barman \& Rusch, 1978). And this has led to the need for consideration of ethical suitability in scientific research and application.

Instead of acting irresponsibly by implementing what is possible and feasible with the technology available in this century, it has become a necessity to set the boundaries of technological interventions in consideration of majority interest. Deciding whether a change is good or bad and right or wrong, asking essential questions regarding to what extent and how something should be defended and producing related answers are all covered in the field of bioethics. In modern societies, people not only have to adapt to the scientific and technological developments, but they also have to face the effects of these technologies and to make a choice when needed (Keskin-Samanc1, 2009; Keskin, Samanc1, \& Kurt, 2013). With the use of these technologies, social, legal, cultural and ethical problems arise in terms of human environment and relations with other species, or it is foreseen that it will occur in the future. For this reason, today we are often faced with the question, "Although it is technically possible now, is it 
right to do it?' Bioethics is defined as a systemic thinking process for making ethical decisions against a dilemma and determining the most morally accurate choice among conflicting options (Berggen, Begat, \& Severinsson, 2002). Today, it is almost possible to find newspapers without environmental terms such as "perforation of the ozone layer", "greenhouse effect" and "forest destruction", or terms such as "cloning of human embryos", "surrogacy", "gene therapy" and "genetic screening". The concept of bioethics examines ethical issues related to all living beings living in the ecosystem (Yıldırım \& Çobanoğlu, 2009).

Studies suggest that individuals must have scientific background (Olsher \& Dreyfus, 1999) and reasoning skill, in short, they should have scientific literacy, in order to use their knowledge for the evaluation of personal and social topics and to set forth opinions through ethical decision-making process (Sadler \& Zeidler, 2005; Hanegan, Price, $\&$ Peterson, 2008). Today, people can reach more information faster than ever, however, not all of this information is scientific. Therefore, individuals must make decisions about the reliability of the information on health, environment and socio-scientific topics. In such cases, scientific literacy, which is someone scientifically literate needs to be able to use scientific and mental processes to solve problems and problems that are of science in everyday life and to make informed decision, plays an important role in helping to make suitable decisions. According to Zeidler and Sadler (2010), "Scientific literacy in the field of socio-scientific issues, social justice experience, tolerance for dissenting voices, mutual respect for cultural differences, and decision making by evaluating the data or being aware of how these actions may affect the community, and the environment to provide them should be provided to students (p. 179)".

First thing to do for analyzing a dilemma in bioethics is information gathering. Some ethical issues create dilemma only due to the lack of information on a given topic. Thus, this first step is the most important but most ignored step (Velasques, Andre, Shanks, \& Meyer, 1996). Nevertheless, gathering information about a topic is not enough by itself. Even though information gathering shows us what is what, it does not say the way things should be. In addition to information gathering, certain skills are also necessary to analyze ethical issues. One of these skills is empathy. Although there are many different definitions for empathy, it is generally defined as "comprehension of another person's emotional state or condition and emotional response to the emotional state of another" (Eisenberg \& Liew, 2009, p. 1). The skill or ability of a person to adapt socially depends on the person's emotions, behavior and interpretation of other people's intentions (Foote \& Cottrel, 1955; quoted by Hançer \& Tanrısevdi, 2003). Empathy enables problem-solving since person gains awareness about their personal experiences and starts to see the source and solutions of issues with their empathy skill (Özcan, Oflaz, \& Türkbay, 2003). As a skill, empathy can be helpful for accurate identification of problems. Empathy; is to understand the feelings and thoughts of the other people and to put oneself in someone else's shoes. Empathy is an ability which positively affect problem solving skills, especially social problem-solving skills.

Considering the increasing news reports on bioethical advances on the front pages of the newspapers, it has become a need for young people to approach and evaluate scientific knowledge from a critical point of view (Lindell \& Milczarek, 1997; Kolsto, 2001). Students encounter many bioethical stories through television, social media or newspapers; and it is likely that they already have heard about many of the social problems stated in these stories. However, their opinions on these topics are only limited with what they hear. Students must be provided with the awareness about how to think against such problems. Today's students will experience different forms on new technologies. Thus, students must acquire awareness on knowledge, skill and social impacts of these technologies in order for them to engage in the dialogue between policymakers and citizens and to make ethical decisions (Kolarova \& Denev, 2012). Teachers are the ones that will provide basic knowledge and ethical decision-making ability to enable social literacy and awareness, and in order for teachers to raise qualified individuals who can adapt to the changing world, teachers themselves must possess such knowledge and skills in the first place and teacher education programs should be expected to provide these knowledge and skills to the teacher candidates. In this study, bioethical values of teacher candidates in science teacher education program were investigated based on their grade levels and the relation of scientific literacy and empathy levels with bioethical values was established. In this study, answers to the following questions were sought "How the pre-service teachers' bioethical values, scientific literacy levels and empathy skills have changed on the basis of grades?" and "What is the relationship between the pre-service teachers' bioethical values, empathy and scientific literacy levels?"

\section{Method}

\subsection{Research Design}

The aim of this study is to evaluate science teacher candidates based on bioethical values, scientific literacy level and empathy skills and to determine their associations. Therefore, simple descriptive survey approach was used for 
the study. The simple descriptive survey approach is one-shot survey for the purpose of describing the characteristics of a sample at one point in time apart from the other approaches of survey research, namely cross-sectional and longitudinal (Mertens, 1998, p. 108). In this research, simple descriptive survey is conducted for the purpose of describing the bioethical values, scientific literacy levels and empathy levels of cohorts of science teacher candidates.

\subsection{Survey Participants}

Participants are pre-service science teachers of the faculty of education from a state university in one of the cities located on the west of Turkey. This was a quantitative study and consisted of 286 voluntary teacher candidates who had enrolled in the Primary Science Teacher Education Program (PSTEP) during the spring of 2017. There were 79 first graders, 70 second graders, 66 third graders and 71 fourth graders. The participants' demographics were similar to the general pre-service science teacher population in Turkey.

\subsection{Data Collection Tools}

Bioethical Values Questionnaire (BVQ), Test of Basic Science Literacy (TBSL) and Cambridge Behavioural Scale (Empathy Quotient - EQ) instruments were used to collect data in the study.

\subsubsection{Bioethical Values Questionnaire}

In this study, Bioethical Values Questionnaire (BVQ), which has originally 21 items, developed by Silva, Araujo, and Calderia (2012) was used. The questionnaire was translated and adapted into Turkish by Turgut and Yakar (2016). The Turkish form of the scale was applied to 420 preservice teachers who continue their education at Pamukkale University and the reliability and validity of the form were tried to be determined. Incomplete surveys were removed from the data set before the analysis of the data obtained. The language of the BVQ is originally Portuguese. However, the developers of the BVQ published their article with English version of BVQ (Silva et. al., 2012). The translation, from English to Turkish was done by two experts who have masters on both Turkish and English and translation of each item on the scale was done separately. These translations were compared by researchers and a translation expert, and translations that are thought to best describe the item in question were adopted. Five voluntary teacher candidates were interviewed face to face for testing to clarity of the scale that is translated in Turkish. Each item was examined one by one and handled until there was no inconsistency and agreement was reached. Finally, by trying not to change the meanings of the items, necessary arrangements were made in the light of the feedbacks given by the teacher candidates and the final version of the Turkish version of the scale was agreed.

Additionally, in pilot study, explanatory and confirmatory factor analyses were conducted. When explanatory factor analysis was used to test factor loadings, items 4, 10 and 19 displayed unsatisfactory loading tendencies; these items were removed from BVQ. Then confirmatory factor analysis was used to test the model's fit. The analysis was conducted with 18 items in four factors that accounted $50.57 \%$ of total variance. For a model with four factors, goodness-of-fit statistics were calculated $(\chi 2=1922.314 ; \mathrm{p}<.05 ; \mathrm{SD}=2.67$; RMSEA=0.06). According to these results, the proper of the model was expected level. Thus, it was established through fit indices that the Turkish version of BVQ comprised 18 items and four factors and that this model was appropriate theoretically and statistically.

BVQ is a Likert-type scale with four subscales and consists of 18 items with "Strongly Agree", "Agree", "Disagree" and, "Strongly Disagree" options. In order to perform analysis based on Bioethical Value questionnaire, bioethical value levels were created by converting numerical values of 1 to 4 into score intervals. Score interval coefficient was calculated according to $n-1 / n$ ratio by subtracting the lowest value from the highest value and dividing the result by the highest value and found to be 0.75 (Büyüköztürk, 2017). Ranges calculated according to this value are as follows; $1.00-1.75$ is "very low"; 1.76-2.5 is "low"; 2.51-3.25 is "moderate"; 3.26-4.00 is "high". Subscales of the questionnaire, definitions of the subscales, example items and Cronbach alpha coefficients are shown in Table 1. 
Table 1. Subscales of bioethical values questionnaire

\begin{tabular}{|c|c|c|c|}
\hline Subscales & Definition of Subscales & Example item & Cronbach $\alpha$ \\
\hline $\begin{array}{c}\text { Benefits of Biotechnology } \\
\text { Applications }\end{array}$ & $\begin{array}{l}\text { Treatment options provided by } \\
\text { biotechnology research }\end{array}$ & $\begin{array}{l}\text { New therapeutic cloning techniques will provide } \\
\text { treatment for many diseases. }\end{array}$ & 0.82 \\
\hline Science and Ethics & $\begin{array}{l}\text { Social awareness about genetic } \\
\text { engineering research }\end{array}$ & $\begin{array}{l}\text { I don't think discussions covering the use of } \\
\text { embryonic stem cell in therapeutic research and } \\
\text { comments based on moral values are related. }\end{array}$ & 0.79 \\
\hline $\begin{array}{l}\text { Reproductive Technologies } \\
\text { and Cloning }\end{array}$ & $\begin{array}{l}\text { Attitudes toward human cloning } \\
\text { and reproductive technologies }\end{array}$ & $\begin{array}{l}\text { If there is a person immune to diseases, I am support } \\
\text { the cloning of that person. }\end{array}$ & 0.70 \\
\hline $\begin{array}{l}\text { Controlling the Genetic } \\
\text { Interventions }\end{array}$ & $\begin{array}{l}\text { Consequences of genetic } \\
\text { interventions and impacts of } \\
\text { genetic manipulations }\end{array}$ & $\begin{array}{l}\text { I believe the ethical issues about genetically } \\
\text { modified foods can be resolved by labelling these } \\
\text { foods and providing the public with the right to } \\
\text { choose whether to consume or not. }\end{array}$ & 0.49 \\
\hline
\end{tabular}

\subsubsection{Test of Basic Science Literacy}

Test of Basic Science Literacy (TBOT) is a scale developed by Miller and it consists of 110 items with true-false-I do not know options for measuring the scientific literacy levels of undergraduate students. TBOT is based on three subscales of scientific literacy projected by Miller (2002); nature of science (22 items), science-technology-society relation (16 items) and scientific content knowledge (72 items). The scale was translated into Turkish by Turgut (2005). Turkish version of the scale is a five-point Likert type scale (strongly disagree $=1$, disagree $=2$, indecisive $=3$, agree $=4$, and strongly agree $=5$ ) and consists 38 items and two subscales of "Nature of Science" and "Science-Technology-Society Relation". Cronbach alpha values for the subscales are 0.88 for nature of science subscale and 0.92 for science-technology-society relation. The high values obtained for both subscales and 0.05 significance found in item-remaining correlation values for both subscales suggest high internal consistency reliability for nature of science and science-technology-society relation of TBOT.

Mean scores of students in subscales of TBOT were assumed to represent their level of understanding in these subscales. Arithmetic mean intervals that form the basis for the evaluation of findings were 1.00-1.80; 1.81-2.60; 2.61-3.40; 3.41-4.20 and 4.21-5.00. These intervals were created by calculating the score interval (Büyüköztürk, 2017). Five scientific literacy categories created by Bybee (1997) were used for corresponding intervals of the study. Score intervals that form the basis for the evaluation of scores obtained from the scale, and the corresponding categories are shown in Table 2.

Table 2. Evaluation intervals of test of basic science literacy

\begin{tabular}{lc}
\hline Level of scientific literacy & Score intervals \\
\hline Illiteracy & $1.00-1.80$ \\
Nominal Literacy & $1.81-2.60$ \\
Functional Scientific and Technological Literacy & $2.61-3.40$ \\
Conceptual and Procedural Literacy & $3.41-4.20$ \\
Multidimensional literacy & $4.21-5.00$ \\
\hline
\end{tabular}

The first level of scientific literacy is illiteracy as shown in Table 2. In this level, individual has no ability or cognitive capacity to understand the concepts, ideas and interactions in order to identify a scientific question. In the nominal literacy, individual may comprehend or appear to have comprehended the questions asked about science, however, has difficulty to answer. In the third level, functional scientific and technological literacy, individual is familiar with the concepts of science and technology and familiar with the terminology. They can define ideas correctly, but not sufficiently. In conceptual and procedural literacy, individual can make interdisciplinary connections and use them in different situations by expanding the characteristics of a discipline. In multidimensional literacy, the highest level of scientific literacy, individual can comprehend the relation of other disciplines with science, technology and society. They notice the daily life situations that require the use of science and include science in this process.

\subsubsection{Cambridge Behavioural Scale (Empathy Quotient)}

Cambridge Behavioural Scale-Empathy Quotient (EQ) was developed by Lawrence, Shaw, Baker, Baron-Cohen and David (2004) and translated into Turkish by Bora and Baysan (2009). EQ is a self-rated instrument that 
includes 40 questions tapping empathy and 20 filler items. Test-retest reliability was assessed by read ministering the scale to 76 students in two weeks' time. For 75 students, EQ assessment that was done by their very close friend was also administered. Cronbach alpha coefficient for the first half of the scale was 0.75 and for the second part was 0.74 . Test-retest reliability of the scale was satisfactory $(0.76)$. These results suggest that the Turkish version of the EQ is a reliable instrument that can be used to measure empathic skills (Bora \& Baysan, 2009).

When answering the test, the questions mark between 4 options with "I strongly agree" and "I strongly disagree" answers at both ends. The total score that can be obtained from the test varies between 0 and 80 . In some questions the "strongly agree" option corresponds to an empathic answer whereas "strongly disagree" is an empathic answer in others. On the scale, on average, most women score 47 and most men score 42, and most people with Asperger syndrome or high-functioning autism score 20 points (Baron-Cohen and Wheelwright, 2004). The score intervals of the scale and their interpretations are as follows:

0-32 = an individual who has less skill than the average empathy ability to understand how other people feel and to give appropriate responses in return.

33-52 = an individual who has average empathy ability to understand how other people feel and to give appropriate responses in return and knows how to act sensitively towards people.

53-63 = an individual who has above-average empathy ability to understand how other people and to give appropriate responses in return.

64-80 = an individual who has very high empathy ability to understand how other people and to give appropriate responses in return. (Guilera, Batalla, \& Soler-González, 2018)

\subsection{Data Analysis}

The data collected via data collection tools were evaluated by using different analysis methods included in the SPSS 23.0 package software. In order to determine whether the data sets have normal distribution to select from parametric and non-parametric tests to be used for the evaluation of the data obtained in the study, "one-sample Kolmogorov - Smirnov Test" was used. In cases with non-homogenous variances, Kruskal Wallis H-Test, a non-parametric test used to test the significance of the difference observed between the points of the groups that belong to the variable, was used. In groups with significant difference according to Kruskal Wallis $\mathrm{H}$ Test, Mann-Whitney $\mathrm{U}$ test was performed in pairs to determine which variables had such difference between values.

Correlation was used to determine the relationship between variables. Correlation coefficients are used to calculate the relationship between two data sets. Correlation coefficients vary between +1 and -1 , and there is a positive relation when it is close to +1 and a negative relation when it is close to -1 . The correlation coefficient of 0 is an indication that there is no relation between the two variables (Büyüköztürk, 2017). Although there are no definite intervals in the interpretation of the magnitude of the correlation coefficient, according to Büyüköztürk (2017) absolute value higher than 0.70 for a correlation coefficient indicates a strong relation, absolute value between $0.70-0.30$ indicates moderate relation and absolute value less than 0.30 indicates poor relation. The relations between the scales were interpreted based on these intervals. As the data of the study was not normally distributed, Spearman correlation analysis, a non-parametric correlation test, was used to determine the relation of bioethical levels with scientific literacy levels and empathy skill.

\section{Results}

1) Bioethical values of teacher candidates based on school year

Changes of science teacher candidates' bioethical value during their preparatory program are presented at Table 3 . Evaluation of the mean scores for the answers to the subscales of Bioethical Value Questionnaire on the basis of school year, mean values were found to increase with school year, although not as much as desired (Table 3). "Science and Ethics" subscales had the highest increase from 2.01 to 2.59 when mean scores of the subscales were evaluated in terms of school year. However, this increment was not enough to move mean scores of the science and ethics subscales away from the "low" category. As data sets of the study were not normally distributed $(\mathrm{K}-\mathrm{S}(\mathrm{z})=0.033 ; \mathrm{p}<0.05)$. Kruskal Wallis test, a non-parametric test, was used to determine whether there was any difference among school years (Büyüköztürk, 2017). Kruskal Wallis test revealed that bioethical values of teacher candidates improved during four-year preparatory program $\left(\chi^{2}=86.21, \mathrm{p}<0.05\right)$. 
Table 3. Descriptive statistical values of subscales of bioethical value questionnaire in terms of school year

\begin{tabular}{ccccccc}
\hline BVS Subscales & Grade & N & Minimum & Maximum & Mean & Bioethical Value Level \\
\hline & 1 & 79 & 2.00 & 4.00 & 3.19 & Moderate \\
Benefits of Biotechnology Applications & 2 & 70 & 2.20 & 4.00 & 3.38 & High \\
& 3 & 66 & 2.40 & 4.00 & 3.28 & High \\
& 4 & 71 & 2.40 & 4.00 & 3.51 & High \\
\hline \multirow{3}{*}{ Science and Ethics } & 1 & 79 & 1.00 & 3.75 & 2.01 & Low \\
& 2 & 70 & 1.00 & 3.25 & 2.15 & Low \\
& 3 & 66 & 1.75 & 3.50 & 2.39 & Low \\
Reproductive Technologies and Cloning & 4 & 71 & 1.50 & 4.00 & 2.59 & Low \\
& 1 & 79 & 1.00 & 4.00 & 2.18 & Low \\
& 3 & 70 & 1.00 & 4.00 & 2.53 & Moderate \\
& 4 & 71 & 1.07 & 4.00 & 2.44 & Low \\
Controlling the Genetic Interventions & 1 & 79 & 2.00 & 3.33 & 2.54 & Moderate \\
& 3 & 70 & 2.00 & 3.50 & 2.75 & Moderate \\
& 4 & 71 & 2.17 & 3.83 & 2.93 & Moderate \\
\hline
\end{tabular}

In order to determine which cohort had these differences, Mann Whitney U test was used. Although there was no statistically significant difference among mean scores of second grade and third grade science teacher candidates, there were significant differences between all other grades with $\mathrm{p}<0.05$. Obtained findings are presented in Table 4. Evaluation of Table 4 shows significant difference between subscales of bioethics questionnaire for teacher

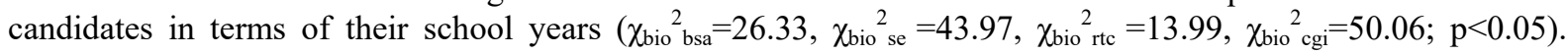
Mann-Whitney U Test was used for groups of two in order to determine which grades had this difference. As a result of the analysis, mean scores of first grade teacher candidates were significantly different than the mean scores of second, third and fourth grade teacher candidates in the Benefits of Biotechnology Applications subscale of Bioethical Value Questionnaire. In Science and Ethics subscale, mean scores of third and fourth grade teacher candidates were significantly different than the scores of first and second grade teacher candidates. In Reproductive Technologies and Cloning subscale, first grade teacher candidates had significantly different mean scores than second, third and fourth grade teacher candidates. In Controlling the Genetic Interventions subscale, there was significant difference between the mean scores of first grade teacher candidates and all other teacher candidates; and between mean scores of second grade and fourth grade teacher candidates.

Table 4. Mann Whitney U test analysis results in terms of school year for subscales of bioethical value questionnaire of science teacher candidates

\begin{tabular}{ccccccc}
\hline & Class & $\mathrm{N}$ & Mean Rank & $\chi^{2}$ & $\mathrm{p}$ & Difference \\
\hline & 1 & 79 & 112.93 & & & \\
Benefits of Biotechnology Applications & 2 & 70 & 152.21 & 26.333 & 0.00 & $1-2,1-3,1-4$ \\
& 3 & 66 & 132.62 & & & \\
& 4 & 71 & 179.04 & & & \\
Science and Ethics & 1 & 79 & 107.03 & & & \\
& 2 & 70 & 124.68 & & & \\
& 3 & 66 & 157.58 & 43.971 & 0.00 & $1-3,1-4,2-3,2-4$, \\
& 4 & 71 & 189.56 & & & \\
Reproductive Technologies and Cloning & 1 & 79 & 115.92 & & & \\
& 2 & 70 & 152.46 & & & \\
& 3 & 66 & 145.69 & & & \\
& 4 & 71 & 163.999 & & 0.00 & $1-2,1-3,1-4$ \\
Controlling the Genetic Interventions & 1 & 79 & 93.35 & & & \\
& 2 & 70 & 143.78 & \multirow{2}{*}{50.065} & 0.00 & $1-2,1-3,1-4,2-4$ \\
& 3 & 66 & 158.68 & & & \\
\hline
\end{tabular}


2) Scientific literacy levels of teacher candidates based on school year

Evaluation of the mean scores for the answers to the subscales of Test of Basic Science Literacy on the basis of school year, mean scores were found to increase with school year (Table 5). In the "Nature of Science" subscale, first and second grade teacher candidates had functional scientific and technological literacy while third and fourth graders had conceptual and methodological level of scientific and technological literacy. In "Science-Technology-Society" subscale; first, second and third grade teacher candidates had functional scientific and technological literacy, whereas only fourth grade teacher candidates were able to rise to the conceptual and methodological level of scientific literacy. Kolmogorov-Smirnov test was used to determine whether the data collected from Test of Basic Science Literacy was normally distributed or not; and the data was found to have no normal distribution $(\mathrm{K}-\mathrm{S}(\mathrm{z})=0.00 ; \mathrm{p}<0.05)$. Non-parametric Kruskal Wallis $\mathrm{H}$ Test was used to determine the presence of any difference in terms of school year for subscales of Test of Basic Science Literacy. Kruskal Wallis test revealed higher levels of scientific literacy for teacher candidates with increased school year $\left(\chi^{2}=52,741\right.$, $\mathrm{p}<0.05)$. Data were evaluated in groups of two with Mann Whitney $U$ test to determine between which school years there was significant difference and results are presented in Table 6.

Table 5. Descriptive statistical values of subscales of test of basic science literacy

\begin{tabular}{ccccccc}
\hline & Class & $\mathrm{N}$ & Minimum & Maximum & $\overline{\mathrm{X}}$ & Level of Scientific Literacy \\
\hline \multirow{3}{*}{ Nature of Science } & 1 & 79 & 2.27 & 4.18 & 3.32 & Functional Scientific and Technological Literacy \\
& 2 & 70 & 2.45 & 4.27 & 3.39 & Functional Scientific and Technological Literacy \\
& 3 & 66 & 2.86 & 4.95 & 3.49 & Conceptual and Methodological Scientific Literacy \\
& 4 & 71 & 3.14 & 4.41 & 3.69 & Conceptual and Methodological Scientific Literacy \\
\hline \multirow{5}{*}{ Science-Technology-Society Relation } & 1 & 79 & 2.56 & 4.25 & 3.21 & Functional Scientific and Technological Literacy \\
& 2 & 70 & 2.44 & 4.44 & 3.35 & Functional Scientific and Technological Literacy \\
& 3 & 66 & 2.50 & 4.63 & 3.35 & Functional Scientific and Technological Literacy \\
& 4 & 71 & 2.88 & 4.63 & 3.55 & Conceptual and Methodological Scientific Literacy \\
\hline
\end{tabular}

Table 6 shows the groups for which significant differences were observed with $\mathrm{p}<0.05$ significance level for "Nature of Science" (NS) and "Science-Technology-Society Relation" (STS) subscales. Study results indicate significant difference with 0.05 significance level in terms of school year between subscale scores of teacher candidates' test of basic science literacy. Evaluation of mean ranks of NS and STS subscales revealed that fourth graders had the highest mean values for both classes.

Table 6. Mann Whitney U test results in terms of school year for subscales of test of basic science literacy

\begin{tabular}{ccccccc}
\hline & Class & $\mathrm{N}$ & Mean Rank & $\chi^{2}$ & $\mathrm{p}$ & Difference \\
\hline & 1 & 79 & 112.35 & & & \\
Nature of Science & 2 & 70 & 126.99 & & & \\
& 3 & 66 & 144.00 & 40.219 & 0.00 & $1-3,1-4,2-4,3-4$ \\
& 4 & 71 & 193.77 & & & \\
\hline \multirow{5}{*}{ Science-Technology-Society Relation } & 1 & 79 & 106.78 & & & \\
& 2 & 70 & 139.11 & & & \\
& 3 & 66 & 139.99 & 39.776 & 0.00 & $1-2,1-3,1-4,2-4,3-4$ \\
& 4 & 71 & 191.49 & & & \\
\hline
\end{tabular}

3) Empathy values of teacher candidates based on school year

Results obtained from the mean scores of the answers given by the science teacher candidates to Cambridge Behavioural Scale are presented in Table 7. 
Table 7. Descriptive statistical values of Cambridge behavioural scale

\begin{tabular}{ccccccc}
\hline & Class & $\mathrm{N}$ & Minimum & Maximum & $\overline{\mathrm{X}}$ & Level of Empathy \\
\cline { 2 - 7 } Empathy & 1 & 79 & 30 & 66 & 46.36 & Average \\
skill & 2 & 70 & 30 & 70 & 44.44 & Average \\
& 3 & 66 & 30 & 68 & 49.03 & Average \\
& 4 & 71 & 35 & 72 & 50.94 & Average \\
\hline
\end{tabular}

According to Table 7, all science teacher candidates had moderate level of empathy skill and empathy scores increased with school year. Kolmogorov-Smirnov test was used to test normality of the data collected from Cambridge Behavioural Scale and the empathy scores were found to have no normal distribution $(\mathrm{K}-\mathrm{S}(\mathrm{z})=0.034$; $\mathrm{p}<0.05)$. Non-parametric Kruskal Wallis $\mathrm{H}$ Test was used to determine the presence of any difference among school years. Analysis revealed significant difference with $\mathrm{p}<0.05$ significance level among empathy score of students in different grades $\left(\chi^{2}=16.095 ; \mathrm{p}<0.05\right)$.

Table 8. Mann Whitney U test analysis results in terms of school year for empathy scores of science teacher candidates

\begin{tabular}{cccccccc}
\hline & Class & $\mathrm{N}$ & Mean Rank & $\mathrm{Sd}$ & $\chi^{2}$ & $\mathrm{p}$ & Difference \\
\hline \multirow{5}{*}{ Empathy skill } & 1 & 79 & 133.65 & & & & \\
& 2 & 70 & 119.55 & & & & \\
& 3 & 66 & 149.48 & 3 & 16.095 & 0.001 & $1-4,2-3,2-4$ \\
& 4 & 71 & 172.51 & & & & \\
\hline
\end{tabular}

Mann Whitney U test was used to determine the grades with the significant differences observed in terms of school years and the empathy scores of fourth grade teacher candidates, who had the highest mean rank, were significantly different than the scores of first and second grade teacher candidates (Table 8). There was also a significant difference between the Cambridge Behavioural Scale answers of second and third grade science teacher candidates $(\mathrm{p}<0.05)$.

4) The relation between bioethical values and scientific literacy levels of teacher candidates

Spearman correlation analysis was used to determine whether there was a relation between bioethical values and scientific literacy levels of science teacher candidates. As a result of Spearman Correlation analysis, a directly proportional and very weak relation with $\mathrm{p}<0.05$ significance level was found between bioethical values and scientific literacy levels of science teacher candidates $(r h o=0.128 ; \mathrm{p}<0.05)$. A low and positive relation with 0.05 significance level was found between nature of science and science-technology-society relation subscales of Test of Basic Science Literacy and the bioethical values (Table 9).

Table 9. Results of correlation analysis between bioethical values of science teacher candidates and subscales of test of basic science literacy

\begin{tabular}{cccc}
\hline \multirow{3}{*}{ Bioethics } & Spearman correlation coefficient & $\mathrm{p}$ \\
\cline { 2 - 4 } & Nature of Science & $0.169^{*}$ & 0.004 \\
& Science-Technology- Society Relation & $0.203^{*}$ & 0.001 \\
\hline
\end{tabular}

Results of Spearman Correlation analysis, which was used again to determine whether there was a relation between bioethical subscales and scientific literacy subscales in science teacher candidates, revealed that subscale of nature of science had a positive and weak relation with subscales of benefits of biotechnology applications and controlling the genetic interventions, whereas, it had a very low and negative relation with the subscale of reproductive technologies and cloning. In addition, the subscale of science-technology-society relation had a positive and low relation with subscales of benefits of biotechnology applications and controlling the genetic interventions (Table 10). 
Table 10. Results of correlation analysis between bioethical values of science teacher candidates and subscales of test of basic science literacy

\begin{tabular}{cccccc}
\hline & & $\begin{array}{c}\text { Benefits of } \\
\text { Biotechnology } \\
\text { Applications }\end{array}$ & $\begin{array}{c}\text { Science } \\
\text { and Ethics }\end{array}$ & $\begin{array}{c}\text { Reproductive } \\
\text { Technologies and } \\
\text { Cloning }\end{array}$ & $\begin{array}{c}\text { Controlling the } \\
\text { Genetic } \\
\text { Interventions }\end{array}$ \\
\hline Nature of Science & $\begin{array}{c}\text { Spearman cor. } \\
\text { coefficient } \\
\text { P }\end{array}$ & $0.247^{*}$ & 0.046 & $-0.135^{*}$ & $0.237^{*}$ \\
\hline $\begin{array}{c}\text { Science-Technology-Society } \\
\text { Relation }\end{array}$ & $\begin{array}{c}\text { Spearman cor. } \\
\text { coefficient } \\
\mathrm{P}\end{array}$ & 0.000 & 0.440 & 0.022 & 0.000 \\
\hline
\end{tabular}

5) The relation between bioethical values and empathy skills of teacher candidates

Spearman correlation analysis was used to determine whether there was a relation between bioethical values and empathy skills of science teacher candidates. Analysis results are presented in Table 11.

Table 11. Results of correlation analysis between empathy skills of science teacher candidates and subscales of bioethics

\begin{tabular}{cccc}
\hline & & Spearman correlation coefficient & $\mathrm{p}$ \\
\cline { 2 - 4 } Empathy & Benefits of Biotechnology Applications & 0.050 & 0.402 \\
skill & Science and Ethics & $0.140^{*}$ & 0.018 \\
& Reproductive Technologies and Cloning & 0.083 & 0.163 \\
& Controlling the Genetic Interventions & $0.152^{*}$ & 0.010 \\
\hline
\end{tabular}

As a result of Spearman Correlation analysis, a directly proportional and poor relation with 0.05 significance level was found between bioethical values and empathy skills of science teacher candidates $(\mathrm{rho}=0.208 ; \mathrm{p}<0.05$ ). Similarly, Table 11 shows a directly proportional and very poor relation with 0.05 significance level between the opinions of science teacher candidates about science and ethics and controlling the genetic interventions topics, and their empathy skills.

\section{Discussion and Conclusion}

Today, science education curriculum includes science and technology together with social, cultural, environmental, political and ethical aspects. Therefore, student's awareness for their own values and being able to explain these values knowingly are very important. And bioethics is required to balance the relation between the values necessary for science and society.

In recent years, topics related to bioethics have gained considerable importance as a significant tool in science education to improve the scientific literacy of students (Chen \& So, 2017; Putri, Tukiran, \& Nasrudin, 2018). In short, it is important for the public to have higher scientific literacy. Science education has a central role for the development of scientific literacy. Today, science education curriculum in many different counties has the goal of achieving scientific literacy at the level of a nation or whole society rather than merely transmitting scientific knowledge to students (NRC, 2012; FNBE, 2014; MEB, 2018; ACARA, 2018). Teachers are the ones that will provide basic knowledge and ethical decision-making ability, and in order for them to raise empathic and scientifically literate individuals, teachers must possess such knowledge and skills in the first place. One of the objectives of this study is to evaluate science teacher candidates' bioethical values in terms of grade level. Study results showed that first grade science teacher candidates had "low" level of bioethical values, whereas, second, third and fourth grade science teacher candidates had "moderate" level of bioethical values. On the basis of this result, it can be said that science teacher candidates generally have moderate level of bioethical values. This result is consistent with the other studies where the opinions on biotechnology were measured (Lock \& Miles, 1993; Chen \& Raffan, 1999; Dawson \& Schibeci, 2003; Prokop, Leskova, Kubiatko, \& Diran, 2007; Özel, Erdoğan, Uşak, \& Prokop, 2009). In addition, bioethical values of the students increased with their grade levels. This result indicates that level of bioethical values of teacher candidates increase as they progress during the teacher education program, although not as much as desired. The most important reason for this is the lectures provided to the teacher candidates during their education. "Science and ethics" subjects are generally discussed in lectures like "Scientific Research Methods" and "Nature of Science and Science History". In these lectures, teacher candidates are 
frequently reminded of ethical values for their homework, projects and presentations and ethics in scientific studies are addressed and discussed from various perspectives like personal interests, social progress and scientific advances. These practices can be said to be effective for the development of scientific and ethical values of teacher candidates.

Another objective of this study is to evaluate science teacher candidates' level of scientific literacy in terms of grade levels. According to the results obtained from the data collected from Test of Basic Science Literacy, scientific literacy of teacher candidates increased in both "Nature of Science" and "Science-Technology-Society Relation" subscales in terms of grade level, although not as much as desired. Results showed that first and second grade teacher candidates had "functional scientific and technological literacy", whereas, third and fourth graders had "conceptual and methodological scientific literacy". Based on this result of the research, it can be concluded that first and second grade science teacher candidates are generally aware of the science and technology terminology and can often define the ideas and concepts in these two fields correctly, although they are not sufficient to interpret the scientific subjects. In addition, it can be said that third and fourth grade teacher candidates can make interdisciplinary connections and use the characteristics of a discipline in different situation and interpret scientific topics. This increment in terms of grade levels observed in the level of scientific literacy of science teacher candidates can be explained by the education they receive during their teacher training program. Especially the lectures such as Nature of Science and Science History, Special Issues in Biology, Special Issues in Chemistry, Special Issues in Physics and the practices performed in these lectures can be said to be effective in the development of scientific literacy of teacher candidates. One of the main objectives of science education is to raise scientifically literate individuals and it is only natural that the education provided for teacher candidates increase their level of scientific literacy. However, the low level of scientific literacy observed in first and second grade teacher candidates indicate that they had significantly low level of scientific literacy when they started their teacher education program. In recent years, there have been frequent changes in science programs in Turkey and the lack of necessary pilot studies and preliminary preparations for these changes, the lack of adequate introduction of new programs to science teachers, the inadequate use of written and visual resources, adversely affect the scientific literacy level of students and it is a significant negativity in achieving the objectives of science programs (MEB, 2012, 2017, 2018).

The study also found moderate level of empathy skills in teacher candidates and that this level increased with school year. Science teacher candidates who participated in the study had average empathy ability to understand how other people feel and to give appropriate responses in return and knew how to act sensitively towards people. In a study conducted by Ekinci (2009) significant difference was found between the grade levels of teacher candidates and their empathy skills and fourth grade students had higher level of empathy skill than first graders. Mete and Gerçek (2005) and Karakaya (2001) obtained consistent results with this study. The presence of such difference can be an indication that empathy skill can be developed and increase over time. In this study, science teacher candidates' empathy skills level was found "average" level. Although this level is better than "less than average" level, it is not enough for future teachers and this does not meet our expectations. The level of empathy of teacher candidates may be due to the decreased creativity as a result of "fear of missing out" and technology dependence caused by the social media use of today's youth and their development of ego-centric personality in line with the "approval seek" behaviour with new technologies. Today, it is a known fact that syndromes such as internet addiction, liking the posts in social media, constantly checking e-mails and messages weaken the creativity and empathy skills of the youth (Bayhan, 2013). As curiosity and creativity are important factor to establish empathy (Alisinanoğlu \& Köksal, 2000) the lack of face-to-face and effective communication of the youth due to new communication technologies may be weakening their empathy skills. Similarly, it is impossible for an ego-centric individual to wonder about other people, imagine what would it be like to be in other people's situation and see the events through their perspectives and thus, this result of the research may be caused by the ego-centric lifestyle of today's teacher candidates.

Another result of the research was that the teacher candidates' opinions on the nature of science and the bioethical value's benefits of biotechnology applications and controlling the genetic interventions subscales had a positive effect on each other. This has similarities with the results of the study conducted by Sönmez and Pektaş (2017). This result showed that teacher candidates were aware of the changeable nature of science while judging topics on biotechnology and genetic interventions. However, a weak and negative relation was determined between the values for the reproductive technologies and cloning subscale and scientific literacy level in the subscale of nature of science in teacher candidates. Detailed evaluation of the research results revealed that teacher candidates had mixed emotions in the "Reproductive Technologies and Cloning" subscale of Bioethical Values Questionnaire. Topics related to this subscale may not have been associated with the nature of science when discussed in the 
lectures and therefore teacher candidates addressed these independently, failing to associate them. Answers given by the teacher candidates to the items of the related subscale of Bioethical Value Questionnaire without considering the fact that "the outcomes of science are social activities that mostly depend on social acceptability" may have led to contradiction with the answers they had given in the nature of science subscale.

There was a weak and positive relation between "Science-Technology-Society" subscale of Test of Basic Scientific Literacy and "Benefits of Biotechnology Applications" and "Controlling the Genetic Interventions" subscales of Bioethical Value Questionnaire. As topics about biotechnology applications and genetic interventions are included in the field of science-technology-society, this can be considered as an expected result. However, in order to reinforce this relation, socio-scientific issues about biotechnology applications and genetic interventions should be addressed more frequently in the lectures of science teacher education programs and teaching methods adopted in these lessons should be reviewed.

Another important result of the research was the positive impact between the level of empathy skill and bioethical values. The findings of the study have also shown that teacher candidates whom have empathy skill will have high level of ethical decision-making. This case shows similarity with the results of the studies conducted by Knight (1989), Reeves, Bowman, and Cooley (1989) and Roßnegel (2004) in the literature.

When the fact that the emotions affect the reasoning and decision-making process in controversial topics it is possible to say in this study that the empathy skills and scientific literacy of the science teacher candidates increases bioethical values which require especially evaluating the data and decision-making. The empathy skill may help the individuals to match their information with the justifications about the subject they have to decide for. In order to ensure this in science education the teacher education programs should make time for education programs, which will create chance for using emotional skills. Socio-scientific topics can be a proper ground for this. For instance, teaching how to make bioethical decisions requires having students face with the real-world scientific dilemmas without trying to provide strident solutions to challenge their conscience or characters. If we want to raise scientifically literate teachers with high empathy skills and who can study the subjects from more than one perspective, then we need to involve socio-scientific topics in the lessons of teacher education program more and we need to have them gaining experience which will have them approach to many scientific problems of the world from different angles by involving the social concepts of these topics into the classroom practices. We need to know well about the factors developing and blocking the healthy decision making and we need to support development of empathy skill which is the most essential factor in understanding the other person in future teacher candidates. By this way the teacher candidates can develop the skills to help distinguishing the opinions lacking the scientific grounds and progress in being scientifically literate citizens.

\section{Limitation and Recommendation for Future Studies}

Today's bioethical problems cause problems that our students will face in the future. Making effective decisions about these problems will require ethical value, which is an important element for the development of scientific literacy. For this, scientific and technological developments and the impact of these developments on society and the impact of society on these developments should be frequently discussed in the lessons. During some courses, considering the necessity of ethical education for science teacher candidates who are tried to be teaching only in the subject, bioethics education should be a part of the current science teacher education program.

Although the results of this study have important implications for the development of scientific literacy, this research is a simple descriptive study and is limited to the data collected by the quantitative measurement tools used. In order to obtain more comprehensive data in future studies on teacher education program, researchers may be recommended to provide data diversity by using different research methods and techniques. Throughout the program, a longitudinal study can be conducted on how science teacher candidates' bioethical values, scientific literacy levels, and empathy skills actually develop. Considering the importance of the subject, it can be said that this issue should be investigated not only in science teacher training program, but in all teacher training programs and at all educational level.

\section{Acknowledgements}

We wish to thank Pamukkale University-Scientific Research Center for their financial support towards the completion of this project.

\section{References}

Alisinanoğlu, F., \& Köksal, A. (2000). Gençlerin ben durumları (ego state) ve empatik becerilerin incelenmesi (Examining young people's ego states and empathic skills). Hacettepe Üniversitesi Ë̆itim Fakültesi Dergisi, 18(18), 11-16. Retrieved from https://dergipark.org.tr/tr/download/article-file/87996 
Australian Curriculum, Assessment and Reporting Authority. (2017). Retrieved from https://www.acara.edu.au/curriculum/foundation-year-10/learning-areas-subjects/science

Barman, C. R., \& Rusch, J. J. (1978). Bioethics: A rationale and a model. American Biology Teacher, 40(2), 85-90. https://doi.org/10.2307/4446165

Baron-Cohen, S., \& Wheelwright, S. (2004). The empathy quotient: an investigation of adults with Asperger syndrome or high functioning autism and normal sex differences. J Autism Dev. Disord., 34, 163-175. https://doi.org/10.1023/B:JADD.0000022607.19833.00

Bayhan, V. (2013). Gençlik, Sosyal Medya ve İnternet Bağımlılığı (Youth, Social Media and Internet Addiction). Düşünce Dünyasinda Türkiz Siyaset ve Kültür Dergisi, 23, 61-80. Retrieved from https://www.tasav.org/media/k2/attachments/23.pdf

Berggren, I., Bégat, I., \& Severinsson, E. (2002). Australian clinical nurse supervisors' ethical decision-making style. Nursing \& health sciences, 4(1-2), 15-23. https://doi.org/10.1046/j.1442-2018.2002.00096.x

Bora, E., \& Baysan, L. (2009). Empati Ölçeği-Türkçe Formunun Üniversite Öğrencilerinde Psikometrik Özellikleri (Psychometric features of Turkish version of empathy quotient in university students). Klinik Psikofarmakoloji Bulteni, 19(1).

Büyüköztürk, Ş. (2017). Handbook of data analysis for social sciences. Pegem Attf İndeksi, 1-231.

Bybee, R. W. (1997). Achieving scientific literacy: From purposes to practices. Heinemann, 88 Post Road West, PO Box 5007, Westport, CT 06881.

Chen, S. Y., \& Raffan, J. (1999). Biotechnology: Student's knowledge and attitudes in the UK and Taiwan. https://doi.org/10.1080/00219266.1999.9655678

Chen, Y., \& So, W. W. M. (2017). An investigation of mainland china high school biology teachers' attitudes toward and ethical reasoning of three controversial bioethics issues. https://doi.org/10.1186/s41029-016-0012-6

Dawson, V., \& Schibeci, R. (2003). Western Australian school students' understanding of biotechnology. International Journal of Science Education, 25(1), 57-69. https://doi.org/10.1080/09500690210126720

Eisenberg, N., \& Liew, J. (2009). Empathy. In R. A. Shweder, T. R. Bidell, A. C. Dailey, S. D. Dixon, P. J. Miller and J. Modell (Eds.).

Ekinci, O. (2009). Analysis of the empathy and the critical thinking disposition of the teacher candidates (Master's thesis, Çukurova University, Adana, Turkey). Retrieved from https://tez.yok.gov.tr/UlusalTezMerkezi/tezSorguSonucYeni.jsp

FNBE. (2014). Perusopetuksen opetussuunnitelman perusteet (National Core Curriculum for Basic Education). Helsinki: Opetushallitus. Retrieved from https://minedu.fi/yleissivistava-koulutus-lainsaadanto

Foote, N. N., \& Cottrell, L. S. (1955). Identity and interpersonal competencies. Chicago: Univer.

Guilera, T., Batalla, I., \& Soler-González, J. (2018). Empathy and specialty preference in medical students.

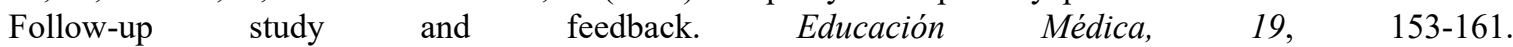
https://doi.org/10.1016/j.edumed.2017.07.017

Hançer, M., \& Tanrisevdi, A. (2003). Sosyal zeka kavraminin bir boyutu olarak empati ve performans üzerine bir inceleme (The Concept of Empathy and Performance as an Aspect of Social Intelligence). CU Sosyal Bilimler Dergisi, 27(2), 211-225. Retrieved from http://eskidergi.cumhuriyet.edu.tr/makale/634.pdf

Hanegan, N. L., Price, L., \& Peterson, J. (2008). Disconnections between teacher expectations and student confidence in bioethics. Science \& Education, 17(8-9), 921-940. Retrieved from https://link.springer.com/article/10.1007\%2Fs11191-007-9122-6

Karakaya, A. D. (2001). Akdeniz Üniversitesindeki Hemşirelik Öğrencilerinin Empati Becerileri (Empathy Skills of Nursing Students at Akdeniz University). İstanbul Üniversitesi. Sağlık Bilimleri Enstitüsü. Yüksek Lisans Tezi. İstanbul. Retrieved from https://tez.yok.gov.tr/UlusalTezMerkezi/tezSorguSonucYeni.jsp

Karasar, N. (2006). Bilimsel Araştırma Yöntemi (Scientific Research Method). Ankara: Nobel yayın Dağıtım.

Keskin, Ö. M., Samanc1, K. N., \& Kurt, İ. (2013). The Investigation of the Opinions of Teacher Candidates about Current Ethical Issues in Terms of Various Variables. Yüksekögretim ve Bilim Dergisi, 3(2), 142-152. https://doi.org/10.5961/jhes.2013.069 
Keskin-Samanc1, N. (2009). Development of Bioethical Value Inventory for Secondary School Students within the Scope of Bioethics Education (Doctoral Dissertation, Gazi University, Turkey). Retrieved from http://www.acikarsiv.gazi.edu.tr/index.php

Knight, P. (1989). Empathy: Concept, Confusion and Conseguences in "A National Curriculum". Oxford Review of Education, 15(1), 41-53. https://doi.org/10.1080/0305498890150104

Kolarova, T. A., \& Denev, I. D. (2012). Integrating a bioethics course into undergraduate biology education. Biotechnology \& Biotechnological Equipment, 26(1), 2801-2810. https://doi.org/10.5504/BBEQ.2011.0089

Kolstø, S. D. (2001). 'To trust or not to trust...'pupils' ways of judging information encountered in a socio-scientific issue. International Journal of Science Education, 23(9), 877-901. https://doi.org/10.1080/09500690010016102

Lawrence, E. J., Shaw, Baker, D., Baron-Cohen, S., \& David, A. S. (2004). Measuring empathy: Reliability and Validity of the Empathy Quotient. Psychological Medicine, 34, 911-924. https://doi.org/10.1017/S0033291703001624

Lindell, T. J., \& Milczarek, G. J. (1997). Ethical, legal, and social issues in the undergraduate biology curriculum. Journal of College Science Teaching, 26(5), 345. Retrieved from https://eric.ed.gov/?id=EJ543485

Lock, R., \& Miles, C. (1993). Biotechnology and genetic engineering: Students' knowledge and attitudes. Journal of Biological Education, 27(4), 267-272. https://doi.org/10.1080/00219266.1993.9655347

MEB. (2018). Science Course Teaching Program. Retrieved from http://mufredat.meb.gov.tr/Programlar.aspx

Mertens, D. M. (1998). Research Methods in Education and Psychology: Integrating diversity with qualitative and quantitative approaches. London: Sage.

Mete, S., \& Gerçek, E. (2005). PDÖ yöntemiyle eğitim gören hemşirelik öğrencilerinin empatik eğilim ve becerilerinin incelenmesi (The Examination of Empathic Tendency and Skills on Nursing Students Who Are Educated with PBL Method). Cumhuriyet Üniversitesi Hemşirelik Yüksekokulu Dergisi, 9(2), 11-17. Retrieved from http://eskidergi.cumhuriyet.edu.tr/makale/1147.pdf

Miller, J. D. (2002). Civic Scientific Literacy: A Necessity in the 21st Century. Journal of the Federation of American Scientists-Public Interest Report, 55(1), 3-6. Retrieved from https://fas.org/faspir/2002/v55n1/scilit.htm

Olsher, G., \& Dreyfus, A. (1999). Biotechnologies as a context for enhancing junior high-school students' ability to ask meaningful questions about abstract biological processes. International Journal of Science Education, 21(2), 137-153. https://doi.org/10.1080/095006999290750

Özcan, C., Oflaz, F., \& Türkbay, T. (2003). Dikkat eksikliği aşırı hareketlilik bozukluğu ve binişik karşıt olma-karşı gelme bozukluğu olan çocukların anne-babalarının empati düzeylerinin karşılaştırılması (Comparison of Empathy in Parents of Children with Attention - Deficit Hyperactivity Disorder and Co-occurrence of Oppositional Defiant Disorder). Çocuk ve Gençlik Ruh Sağlığ Dergisi, 10(3). Retrieved from http://psikiyatridizini.net/articles.aspx?journalid=17\&year=2003\&volume=10\&number $=3$

Özel, M., Erdoğan, M., Uşak, M., \& Prokop, P. (2009). Lise öğrencilerinin biyoteknoloji uygulamalarına yönelik bilgileri ve tutumları (High School Students' Knowledge and Attitudes Regarding Biotechnology Applications). Science Education, 2(10), 61-69. Retrieved from http://www.zoo.sav.sk/data/people_publictions_993_Ozel_et_al.ESTP09.pdf

Prokop, P., Lešková, A., Kubiatko, M., \& Diran, C. (2007). Slovakian students' knowledge of and attitudes toward biotechnology. International Journal of Science Education, 29(7), 895-907. https://doi.org/10.1080/09500690600969830

Putri, P. D., Tukiran, T., \& Nasrudin, H. (2018). The effectiveness of problem-based Learning (PBL) models based on socio-scientific issues (SSI) to improve the ability of science literacy on climate change materials. $\begin{array}{lllll}\text { JPPS } \quad \text { (Jurnal Penelitian Pendidikan } & \text { Sains), } & 7(2), & 1519-1524 .\end{array}$ https://doi.org/10.26740/jpps.v7n2.p1519-1524

Reeves, T. G., Bowman, J. T., \& Cooley, S. L. (1989). Relationship between the client's moral development level and empathy of the counseling student. Counselor Education and Supervision, 28(4), 299-304. https://doi.org/10.1002/j.1556-6978.1989.tb01120.x

Roßnegel, C. (2004). Cognitive load and perspective taking: applying to verbal communication European. Journal Social Psychology,

30 , 429-445. 
https://doi.org/10.1002/(SICI)1099-0992(200005/06)30:3\%3C429::AID-EJSP3\%3E3.0.CO;2-V

Sadler, T. D., \& Zeidler, D. L. (2005). Patterns of informal reasoning in the context of socioscientific decision making. Journal of research in science teaching, 42(1), 112-138. https://doi.org/10.1002/tea.20042

Silva, P. R., Araújo, E. S. N. N. D., \& Caldeira, A. M. D. A. (2012). Construction and validation of a questionnaire for the analysis of bioethical conceptions. Revista Bioética, 20(3), 488-499. Retrieved from https://repositorium.sdum.uminho.pt/handle/1822/23304

Sönmez, E., \& Pektaş, M. (2017). The Effects of Some Activities of Biotechnology in Extra-Curricular On Middle School Students Nature Of Science Perceptions and Biotechnology Knowledge. Kastamonu Eğitim Dergisi, 25(5), 2019-2036.

Turgut, D., \& Yakar, Z. (2016, December). Adaptation of a modified Turkish version of Bioethical Values Questionnaire (BVQ). Multidisciplinary Academic Conference - Education, Teaching and Learning, At Czech Republic, Prague. Retrieved from https://books.google.com.tr/books?id=3_KpDQAAQBAJ\& printsec $=$ frontcover\&hl $=$ tr\&source $=$ gbs_ge_summary_r\&cad $=0 \# \mathrm{v}=$ onepage\&q\&f=false

Turgut, H. (2005). Yapılandırmacl Tasarım Uygulamasının Fen bilgisi Öğretmen Adaylarının Bilimsel Okuryazarlık Yeterliklerinden Bilimin Doğası ve Bilim- Teknoloji-Toplum İlișkisi Boyutlarının Gelișimine Etkisi (Unpublished doctoral dissertation). Yıldız Teknik University, İstanbul, Turkey.

Velasquez, M., Andre, C., Shanks, T., \& Meyer, M. J. (1996). Thinking ethically: A framework for moral decision making. Issues in Ethics, 7(1).

Wallen, N. E., \& Fraenkel, J. R. (2013). Educational research: A guide to the process. Routledge. https://doi.org/10.4324/9781410601001

Yıldırım, A. E., \& Çobanoğlu, N. (2009). A Bioethical Heritage: Bioethical Values in Traditional Settlements. Ankara University Journal of Social Sciences, 1(1). https://doi.org/ 10.1501/sbeder_0000000005

Note.

Note 1. This article is derived from Duygu Turgut's Master thesis entitled "Investigation of class-based to science teacher candidates' bioethical values, scientific literacy levels and empathy skill", conducted under the supervision of Zeha Yakar.

\section{Copyrights}

Copyright for this article is retained by the author(s), with first publication rights granted to the journal.

This is an open-access article distributed under the terms and conditions of the Creative Commons Attribution license (http://creativecommons.org/licenses/by/4.0/). 